\title{
Mekansal Plan Değişikliklerinin Kentsel Yaşam Kalitesi Üzerine Etkisi: Ankara Çankaya Örneği *
}

\author{
İrem Akkaya Büyükcivelek ${ }^{1}$ \\ ORCID: 0000-0003-2840-0578
}

*

\author{
Çiğdem Varol ${ }^{2}$ \\ ORCID: 0000-0002-2432-5745
}

Öz

Kenti yönetenlerin temel amacının kentlilerin yaşam kalitesini artırmak olduğu üzerine ortaklaşmak olanaklıdır. Ancak yaşam pratiklerimiz kentsel müdahalelerin her zaman kentlilerin yaşam kalitesini arttırıcı etki yapmadı̆̆ını, kimi müdahalelerin yaşayanların yaşam kalitesini düşürücü etkiler yarattı̆̆ını kanıtlar niteliktedir. Deneyimlerin oluşturduğu bu varsayımdan yola çıkan çalışma "kentsel mekansal müdahalelerin kentlilerin yaşam kalitesine etkisinin ne olduğunu" ortaya koymayı amaçlamıştır. Çalışma iki farklı kuramsal yaklaşım üzerinden ilerlemiştir. Illk olarak kentleşme sürecinin önemli bir bileşeni olarak kentsel müdahaleler konusu tart-şılmış, sonrasında ise yaşam kalitesi kavramı ve kentsel yaşam kalitesi tartışmaları ele alınmıştır. Kentsel yaşam kalitesine yönelik çalışmanin ikinci bölümü kapsamında ise; yaşam kalitesi bileşenleri, kente ve mekana ilişkin geliştirilen göstergeler ve göstergelerin değişen bağlamlara göre farklılaşması ele alınmıştır. Kuramsal yaklaşımların alan çalışması ile değerlendirilmesinin amaçlandığı üçüncü bölümde, Ankara ili Çankaya ilçesinde karar alma yetkisi olan farklı aktörlerce yapilan kentsel mekansal müdahalelerin yaşam kalitesine etkisi ortaya konulmaya çalışılmıştır. Bu bağlamda Çankaya İlçesinde mekansal müdahale içeren plan değişiklikleri incelenmiştir. Sonuç bölümünde ise, alan çalı̧ması sonucunda tespit edilen bulgular ortaya konmuş ve kentsel yaşam kalitesini artırmaya yönelik başarll ve etkili politikaların oluşturulması için önerilerde bulunulmuştur.

Anahtar Kelimeler: Kentsel yaşam kalitesi, mekansal plan değişiklikleri, kentsel mekansal müdahale, Ankara-Çankaya

\footnotetext{
* Bu makale çalışması “5.Kent Araştırmaları Kongresi” nde bidiri olarak sunulmuştur.

${ }^{1}$ Gazi Üniversitesi, Çankaya Belediyesi, E-mail: akkayairem@gmail.com

2 Prof. Dr., Gazi Üniversitesi, E-mail: cvarol@gazi.edu.tr

idealkent @ C Kent Araştırmaları Dergisi (Journal of Urban Studies) 


\title{
The Effects of Spatial Plan Revisions on Urban Quality of Life: The Case of Ankara Çankaya
}

\author{
İrem Akkaya Büyükcivelek ${ }^{3}$ \\ ORCID: 0000-0003-2840-0578
}

*

\author{
Çiğdem Varol 4 \\ ORCID: 0000-0002-2432-5745
}

\begin{abstract}
It is possible to agree that the main purpose of those who manage the city is to increase the quality of life of the citizens. However, our life practices prove that urban interventions do not always increase the quality of life of the city dwellers, and even some interventions reduce the quality of life of the concerned population. Based on this assumption, the study aimed to reveal "the effect of urban spatial interventions on the quality of life of the citizens". The study progressed through two different theoretical approaches. First, the issue of urban interventions, as an important component of the urbanization process, was discussed and then the concept of quality of life is discussed with special emphasis on its urban aspect. The second part of the study focused on urban life quality and tried to reveal its components and indicators. The difference among indicators according to varying contexts are discussed in detail. In the third part, theoretical approaches are evaluated with the case study. The effect of urban spatial interventions performed by different actors with decision making authority in Çankaya district of Ankara province on the quality of life is analyzed. In the same vein, plan revisions that cover direct spatial interventions were examined. The conclusion part covered the findings revealed out of the case study and suggestions were made for the creation of successful and effective policies to increase the quality of urban life.
\end{abstract}

Keywords: Urban quality of life, spatial plan revisions, urban spatial intervention, Ankara-Çankaya

\footnotetext{
${ }^{3}$ Gazi Üniversitesi, Çankaya Belediyesi, E-mail: akkayairem@gmail.com

${ }^{4}$ Prof. Dr., Gazi Üniversitesi, E-mail: cvarol@gazi.edu.tr

idealkent @ C Kent Araştırmaları Dergisi (Journal of Urban Studies) 


\section{Giriş}

Günümüzde kentlerde yaşayan nüfusun artması ile kentlerde sağlanması gereken hizmetler de her geçen gün artmaktadır. Bu hizmetlerin sağlanabilmesi için kente mekânsal müdahaleler yapılmaktadır. Kent yöneticileri, karar vericiler ve uygulayıcılar kentsel mekâna yapılan müdahaleler ile kimi zaman kentin kullanıcılarının yaşam kalitesini artırırken, kimi zamanda tam tersine yaşanılmaz mekânlar yaratılmasına sebep olmaktadır.

Her kentsel müdahale kentleşme sürecinin bir parçası olarak alınabilir. Kentleşme süreçlerine ilişkin tartışmalarda Lefebvre (2007), Castells (1997), Harvey (1985) ve Soja (1980) gibi yazarlar kentlerin gelişim süreçlerini temelde siyasal iktisadın bir ürünü olarak ele almışlar, ancak devletin (planlamanın), bireylerin, sermayenin ve siyasetin rolünü tanımlarken çeşitli ayrışmalara gitmişlerdir. Çalışmaların ortak yanı, kapitalist siyasal iktisadın mekân üretim biçimine ve bundan kaynaklanan olumsuzluklara odaklanmalarıdır. Mekânın toplumsal üretimi, mekânsal adalet, kentsel adalet, eşitsizlikler, sermaye döngüleri ve krizleri bu tartışmaların ortak konularıdır.

Yaşam kalitesi kavramının kapsamı ise çok boyutludur. Farklı disiplinlerin araştırma konusu olan kavram, farklı biçimlerde ele alınmaktadır. Yaşam kalitesi en genel anlamda bireylerin içinde yaşadığı çevre koşulları ve kendileriyle ilgili özelliklerinden oluşmaktadır. Çevre koşulları ile bahsedilmek istenen; hava ve su kirliliği, konutun konfor şartları vb. özellikleri iken, kendi ile ilgili özellikler ise sağlık durumu, eğitim seviyesi vb. özelliklerdir (Pacione, 1986). Yaşam memnuniyeti ve refah gibi bazı kavramlar da yaşam kalitesi kavramının yerine kullanılmaktadır.

Çalışma, kentsel mekâna yönelik müdahalelerin insan yaşamında oynadığı önemli rolü gözeterek, bu müdahalelerin kentsel yaşam kalitesi üzerindeki olumlu ve olumsuz etkilerini, Ankara İli Çankaya İlçesi'nde müdahale yetkisi bulunan farklı aktörlerce gerçekleştirilen plan değişiklikleri üzerinden araştırmayı hedeflemektedir. Çalışma kapsamında, 2014-2019 yılları arasındaki yerel ve merkezi yönetimde plan değişikliğinde rol alan tüm kurumların aldığı mekânsal müdahale kararları incelenmektedir.

\section{Kentsel Mekansal Müdahale Süreçleri}

Lefebvre (2007) kapitalist sistemin sürekli bir büyüme ihtiyacı olduğunu, büyümeyi sürdürmesinin de ancak kapitalist sistemin kent mekanını ele 
geçirmesiyle olanaklı olduğunu söylemektedir. Kent mekanını üretim süreçlerini kontrol etmek de sermaye sınıflarının temel amacıdır. Ancak sermaye sınıfları mekanın üretim süreçlerinde diğer toplumsal sınıflarla çatışma halindedir. Devlet, toplumsal düzen sağlamak için mekanı bir siyasi araç ve aygıt olarak görür ve mekanın üretimine sürekli müdahale eder. Altyapı sağlayan, kaynakları yöneten, planlama yetkisine sahip olan devlet, soyut mekânın hiyerarşik düzenlenişinden sorumludur; yerler ve mekânları, işlev ve özelliklerine göre hiyerarşik bir düzene sokarak sorumlu olduğu toplumsal düzenin temellerini sağlar (Ghulyan, 2017).

Harvey (1985) kentsel mekanın üretim süreçleri ile sermaye birikim süreçleri ve sermaye döngülerindeki krizler arasındaki paralellik olduğunu savunmakta ve sermayenin kendini var edebilmek ve sürekliliğini koruyabilmek için mekanı kullandığını vurgulamaktadır. Mekanın metalaşması, ya da mekanın kullanım değerindense değişim değerinin önceliklendirilmesi bunun bir sonucudur.

Diğer yandan Soja (1980) ise mekan üretiminde temel aktör kim olursa olsun, mekan ne şekilde üretilirse üretilsin bu sürecin tek taraflı olamayacağını savunmaktadır. Her mekansal düzenlemenin yaşanmaya başlanmasiyla birlikte tasarlayanlar, uygulayanlar ve yaşayanlar (Lefebvre, 2007) arasında bir etkileşim oluşturduğunu ifade etmektedir. Sermaye çıarlarını önceleyen bir mekansal düzenlemenin Castells'in de vurguladığı gibi toplumsal hareketlerin oluşumuna zemin hazırlaması ve oluşan tepkisellik sonucunda yeniden şekillenmesi sosyo-mekansal bir süreçtir ve mekan bu etkileşim içinde sürekli değişmekte ve yeniden oluşmaktadır. Benzer şekilde Keskinok (1998)' a göre toplumsal olarak üretilen kentsel mekan ne sadece 'olayların geçtiği yer' (locus) ne de sadece 'aktörlerin yöneldiği şey' (focus) olarak kavramsallaştırılabilir. Kentsel mekan bu ikisi arasındaki diyalektik ilişkinin ürünüdür. Mekanın üretimi aktörlerin, bilinçli ve bilinçli olmayan etkinlikleri ve müdahaleleriyle gerçekleşmekte ve süreç içinde mekan yeniden yapılanmakta, yeniden üretilmekte ve dönüşmektedir.

Kentsel mekanın yeniden üretimde yani kentsel mekânsal müdahalelerde başta devlet olmak üzere, mekansal müdahale yetkisi bulunan farklı aktörler bulunmaktadır. Türkiye'deki kentsel mekânsal müdahaleler için temel yasal mevzuat olan 3194 sayılı İmar Kanunu ve Mekansal Planlar İmar Yönetmeliğine göre kentsel alanların çeşitli ölçeklerdeki mekansal planlarını ilgili belediye yapar veya yaptırır. Belediyelere ek olarak gerekli görülen hallerde kamu yapıları, enerji tesisleri, afet, toplu konut, gecekondu, hava meydanı gibi alanlarda Bakanlıklar ve özelleştirme programına alınmış kuruluşlara ait 
arsa ve arazilerde ise Başbakanlık Özelleştirme İdaresi Başkanlığı imar planı yapma, yaptırma ve onaylama yetkisine sahiptir.

$\mathrm{Bu}$ aktörler mekanın üretimi ve yeniden üretiminde imar planları ve imar planı değişiklikleri ile mekânsal müdahaleyi gerçekleştirmekte ve yapılan müdahalenin niteliğine bağlı olarak kentsel yaşam çevreleri olumlu veya olumsuz etkilemektedir. Kentsel mekânsal müdahalelerin kentsel yaşam kalitesine etkilerini anlayabilmek, kentsel yaşam kalitesinin ve göstergelerinin neler olduğunun anlaşılması önemlidir.

\section{Kentsel Yaşam Kalitesi ve Göstergeleri}

Wish (1986)'e göre yaşam kalitesi, çevresel ve psikolojik bileşenleri içeren bir kavram olarak açıklanmaktadır. Bir başka bakış açısına göre, yaşam kalitesi insanın yaşamdan hoşnutluğu ve mutluluğu, insanın mutlu yaşam beklentisi olarak tanımlanmaktadır (Veenhoven, 2000). Diğer yandan Diener ve Suh (1997) yaşam kalitesinin yaşamdan duyulan tatmin olduğunu, Szalai (1980) ise tatmin veya mükemmeliyet derecesine ek olarak, kişinin dıştan gelen (nesnel) etkenler ve içten gelen (öznel) yani kişinin algisı ile değerlendirildiğini ortaya koymaktadır.

Dünya Sağlı Örgütü (DSÖ)'nün yaptığı tanıma göre yaşam kalitesi, kişinin kendi yaşadığ 1 kültürel bağlam ve değer sistemi içindeki, konumu ve algısının ilişkileri, hedefleri, beklentileri, standartları ve kaygıları ile bağlantılıdır (Marsella vd., 1997). Yaşam kalitesi, aynı doğal ve yapılı çevrede yaşayan bireylerin, fiziksel ve psikolojik refahının algılanan durumsal ifadesi (Liu vd., 1986) olarak da tanımlanmaktadır. Raphael ve arkadaşları (1996) farklı bir düşünce geliştirerek yaşam kalitesini, kişinin yaşamın önemli olanaklarından faydalanma derecesi olarak tanımlamıştır.

Musschenga (1997) yaşam kalitesini tanımlarken, zevk alma konusuna odaklanmış ve yaşam kalitesini, iyi bir yaşamın farklı zevk alma düzeylerinin birleşimi olduğunu savunmuştur. Yazara göre üç farklı zevk alma düzeyi vardır. İlki, olumlu bir zihinsel durum, yaşam planının gerçekleşmesi; ikincisi, yaşam planının gerçekleşmesi veya gerçekleşme başarısı veya kişinin iyi bir yaşam algısının oluşması; üçüncüsü ise erdemlilik veya kişinin etkinliklerinin değeridir. Benzer bir düşünce sistemini yans1tan Cheung (1997)'a göre; iyi bir yaşam dört farklı etmenin bileşimi ile olur. Hedonist iyi yaşam; yaşam tatmini, olumlu ve olumsuz etkiler, depresyon. Diyalektik iyi yaşam; kişiler arası karşılıklı kaygı ve başkalarını 
anlama. Hümanist iyi yaşam; insanın yaşam potansiyelini gerçekleştirmesi, bireysel gerçekleşmenin değeri. Formalist iyi yaşam; neyin doğru olduğu ile ilişkili olarak ahlaki kurallara uyumlu dini bağlılık.

Kentsel çevrenin yaşam kalitesine etkisine yönelik ilk çalışma 1969 y1lında Harvey Perloff tarafından yapılmıştır. Perloff (1969), kentsel yerleşme etrafında toplanmış kişilerin yaşam kalitesinin doğal ve insan yapımı çevrenin karşılıklı etkileşmesiyle belirlendiğini ortaya koymaktadır. Yaşam kalitesi her toplum ve toplumda yaşayan her insan için farklıdır. Bunun yanında aynı toplum içinde koşullardaki farklılaşmaya göre de farklılık göstermektedir. Kötü koşullarda yaşam kalitesi tanımlanırken; gıda, güvenlik, barınma ve iş olanakları gibi temel gereksinimler göz önüne alınmaktadır. İyi koşullarda yaşam kalitesi tanımlanırken ise, mutlu toplum, temiz bir çevre, eğlence ve rekreasyon olanaklarına erişim, kişilerin başarılı kişisel ve mesleki hayatı gibi konular içerilecek şekilde geniş bir çerçeveden bakılmaktadır (Andrews, 2001).

Günümüzde planlamanın en önemli hedeflerinden biri yaşam kalitesini artırmaktır diyebiliriz. Tekeli (2009)'ye göre yaşam kalitesi; insan haklarının korunmasında, ekonomik ve sosyal politikaların geliştirilmesinde, sağlık politikalarının yönlendirilmesinde, kentleşme politikalarının düzgün biçimde işletilmesinde, yerel ekonomik gelişmelerin hızlandırılmasında gerçekleştirilmesi gereken temel amaç haline gelmiştir.

Kentsel yaşam kalitesinin ölçülmesi ve değerlendirmesinde farklı yaklaşımlar bulunmaktadır. Akademik yazındaki çalışmalar bir bütün olarak değerlendirildiğinde, üç yaklaşımdan bahsedilebilir (Dissart ve Deller, 2000).

İlk yaklaşım, sadece nesnel göstergeleri ele alarak yaşam kalitesini ölçmeye yöneliktir. Nesnel göstergeler araştırma yapan kişi, kurum veya kuruluşlar tarafından yapılan ölçümler sonucu elde edilen istatistiki veriler ve sayımlar gibi nicel veriler kullanılarak yapılmaktadır. Örneğin; Liu (1976) kentsel yaşam kalitesi göstergelerini nesnel göstergeler üzerinden belirlemiştir. Bu kapsamda 123 değişken incelemiş ve bunları 5 ana başlıkta toplamıştır. Bunlar; (1) ekonomik, (2) politik, (3) çevresel, (4) sağlık ve eğitim, (5) sosyaldir.

İkinci yaklaşım, sadece öznel göstergelerin kullanılarak yaşam kalitesinin ölçülmesini hedeflemektedir. Öznel göstergeler kişinin yaşam hakkında bireysel algı ve değerlendirmesini kapsamaktadır. Bu yaklaşımda kişilere yönelik yapılan özel çalışmalardan elde edilen sonuçlara göre yaşam kalitesi değerlendirmesi yapılmaktadır. Bu sebeple öznel göstergelerle elde edilen veriler kişiden kişiye farklılık göstermektedir. Örneğin; 
Jeffres ve Dobos (1995), algılanan yaşam kalitesi ile ilgili kişilerin yaşamdan memnuniyetini anket yaparak Likert ölçeği ile ölçmeye çalışmışlardır.

Son yaklaşım ise, öznel ve nesnel göstergelerin birlikte kullanılmasıdır. Yani bu yaklaşımda tarama ile elde edilen öznel veriler ile nesnel verileri birleştirerek elde edilen veriler ile çalışma yapılmaktadır. Araştırmalarda sadece öznel veya sadece nesnel göstergelerin kullanılması doğru sonuca ulaşmak için yeterli olmamaktadır. Bu sebeple nesnel ve öznel göstergelerin birlikte kullanılması, konuyla ilgili çok boyutlu değerlendirme yapılmasına yardımcı olmaktadır. Yaşam kalitesi ölçümünde hem öznel hem de nesnel göstergeleri kullanan pek çok araştırma bulunmaktadır (Pacione, 2003; Dissart ve Diller, 2000; Szalai ve Andrews, 1980; Rogerson vd., 1989; Cutter, 1985).

Çalışma kapsamında, uluslararası ve ulusal akademik yazında farklı yazarların kentsel yaşam kalitesinin belirlenmesi amacıyla kullandıkları göstergeler çevre, sosyal, ekonomik ve mekan başlıkları altında dört temel grupta sınıflandırılmıştır. Bu dört grup altında da alt göstergeler sınıflandırılmaktadır (Tablo 1). Bu çalışmada ise ulaşılabilen veriler kısıtı nedeniyle, bu gösterge setlerinden bir kısmı kullanılmakta ve plan değişikliği kararlarının kentsel yaşam kalitesine etkisine bakarken 'sosyal' başlığı altında yer alan eğitim, kültür, sağlık, yeşil alan göstergeleri ve 'mekan' başlığ1 altında yer alan ulaşım, erişebilirlik (kamu hizmetlerine, sağlık, eğitim, spor, ticaret, yeşil alan) ve yapılı çevre-altyapıya ilişkin nesnel göstergeler değerlendirmeye alınmaktadır (Tablo 2). 
Tablo 1. Uluslararası ve ulusal akademik yazındaki kentsel yaşam kalitesi göstergeleri

\begin{tabular}{|c|c|c|}
\hline $\begin{array}{l}\text { Yaşam } \\
\text { kalitesi } \\
\text { temel } \\
\text { göstergeleri }\end{array}$ & $\begin{array}{l}\text { Yaşam kalitesi } \\
\text { göstergeleri }\end{array}$ & Yazar \\
\hline \multirow[t]{3}{*}{ Çevre } & $\begin{array}{l}\text { Kirlilik (hava, su, } \\
\text { gürültü, çöp) }\end{array}$ & \multirow{3}{*}{$\begin{array}{l}\text { Abbate vd. (2001), BİB (2008), Demirkaya (2010), Dülger Tür- } \\
\text { koğlu vd. (2008), Evcil Türksever ve Atalık (2001), Garau ve Pa- } \\
\text { van (2018), Kamp vd.(2003), Marans ve Stimson (2011), McCrea } \\
\text { vd.(2006), Nakanishi (2015), Salihoğlu ve Türkoğlu (2019), San- } \\
\text { tos ve Martins. (2007), Shoja vd.(2015), Tekeli vd. (2003), Tekeli } \\
\text { (2009), Tesfazghi vd. (2010), Ülengin vd. (2001), Yakın İnan ve } \\
\text { Özdemir Sönmez (2019). }\end{array}$} \\
\hline & Trafik & \\
\hline & $\begin{array}{l}\text { Doğal çevre, } \\
\text { doğal kaynaklar }\end{array}$ & \\
\hline \multirow[t]{10}{*}{ Sosyal } & Nüfus & \multirow{10}{*}{$\begin{array}{l}\text { Abbate vd.(2000), BİB (2008), Demirkaya (2010), Dülger Tür- } \\
\text { koğlu vd. (2008), Evcil Türksever ve Atalık (2001), Garau ve Pa- } \\
\text { van(2018), Kamp vd.(2003), Marans ve Stimson (2011), McCrea } \\
\text { vd.(2006), Nakanishi (2015), Salihoğlu ve Türkoğlu (2019), San- } \\
\text { tos ve Martins (2007), Shoja vd.(2015), Tekeli vd. (2003), Tekeli } \\
\text { (2009), Tesfazghi vd.(2010), Ülengin vd. (2001), Yakın İnan ve } \\
\text { Özdemir Sönmez (2019). }\end{array}$} \\
\hline & Eğitim & \\
\hline & $\begin{array}{l}\text { Kültür, kültürel } \\
\text { faaliyetler }\end{array}$ & \\
\hline & Sağlık & \\
\hline & Yeşil alan & \\
\hline & Yaşam biçimi & \\
\hline & Güvenlik (suç) & \\
\hline & Bireyin karakteri & \\
\hline & $\begin{array}{l}\text { Memnuniyet (konut, } \\
\text { komşu, hayat, bölge..) }\end{array}$ & \\
\hline & Katılım & \\
\hline \multirow[t]{4}{*}{ Ekonomik } & $\begin{array}{l}\text { Ekonomi } \\
\text { (yaşam maliyeti) }\end{array}$ & \multirow{4}{*}{$\begin{array}{l}\text { BİB (2008), ), Evcil Türksever ve Atalık (2001), Kamp vd.(2003), } \\
\text { Marans ve Stimson (2011), McCrea vd.(2006), Salihoğlu ve Tür- } \\
\text { koğlu (2019), Santos ve Martins. (2007), Tekeli vd. (2003), Tekeli } \\
\text { (2009), Tesfazghi vd.(2010, Ülengin vd. (2001), Yakın İnan ve Öz- } \\
\text { demir Sönmez (2019). }\end{array}$} \\
\hline & Ev fiyatı & \\
\hline & Gelir & \\
\hline & $\begin{array}{l}\text { Ekonomik canlılık } \\
\text { (işgücü ve konut } \\
\text { piyasası) }\end{array}$ & \\
\hline \multirow[t]{4}{*}{ Mekan } & Ulaşım & \multirow{4}{*}{$\begin{array}{l}\text { Abbate vd. (2001), BİB (2008), Demirkaya (2010), Dülger Tür- } \\
\text { koğlu vd. (2008), ), Evcil Türksever ve Atalı (2001), Garau ve } \\
\text { Pavan (2018), Kamp vd.(2003), Marans ve Stimson (2011), } \\
\text { McCrea vd.(2006), Nakanishi (2015), Salihoğlu ve Türkoğlu } \\
\text { (2019) Santos ve Martins. (2007), Shoja vd.(2015), Tekeli vd. } \\
\text { (2003), Tekeli (2009), Tesfazghi vd.(2010), Ülengin vd. (2001), Ya- } \\
\text { kı İnan ve Özdemir Sönmez (2019). }\end{array}$} \\
\hline & $\begin{array}{l}\text { Erişebilirlik (kamu } \\
\text { hizmetlerine, sağllk, } \\
\text { eğitim, spor, ticaret, } \\
\text { yeşil alan...) }\end{array}$ & \\
\hline & Yapılı çevre, altyapı & \\
\hline & & \\
\hline
\end{tabular}



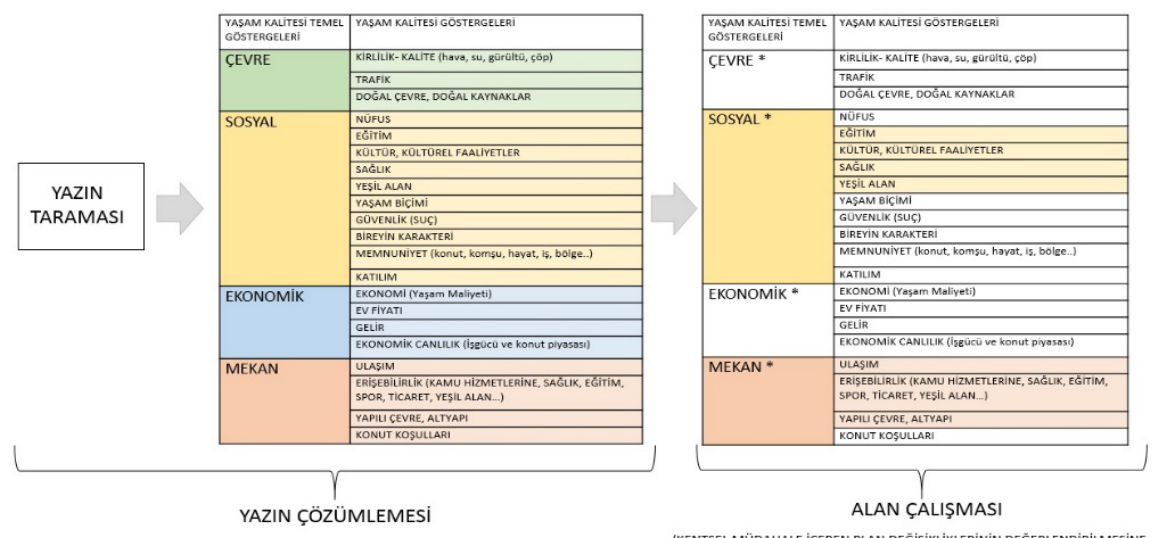

(KENTSEL MŨDAHALE iČEREN PLAN DEĞişiKLIKLERININ DEĞERLENDiRILMESiNE YÖNELIK KULLANILAN KENTSEL YASAM KALLTESI GÖSTERGELERI)

Şekil 1. Alan çalışmasında ele alınan kentsel yaşam kalitesi göstergeleri

Tablo 2. Plan değişiklikleri ile yapılan kentsel müdahalelerin yaşam kalitesine etkisinin ölçülmesine ilişkin nesnel göstergeler

\begin{tabular}{|c|c|c|c|c|c|}
\hline $\begin{array}{c}\text { Yerleşme - } \\
\text { Mekan Kalitesi }\end{array}$ & $\begin{array}{l}\text { Erişebilirlik- } \\
\text { Ulaşım }\end{array}$ & Güvenlik & Ekonomik & $\begin{array}{c}\text { İnsan Kaynağı- } \\
\text { Demografik }\end{array}$ & Çevre \\
\hline 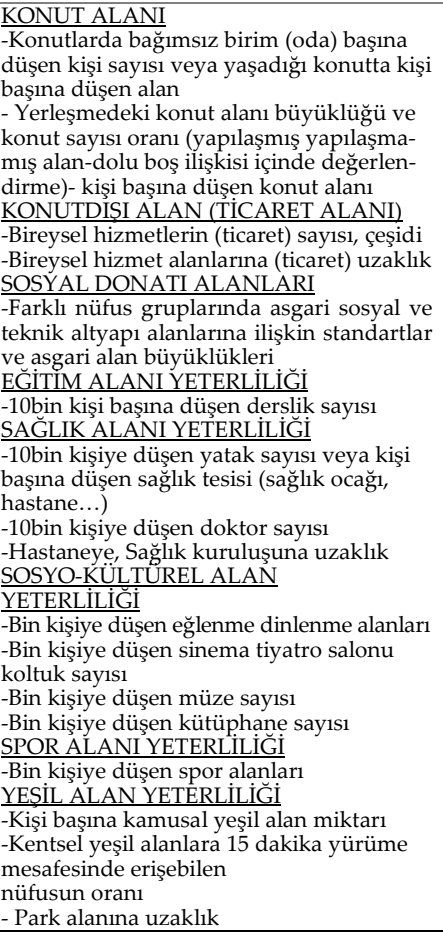 & $\begin{array}{l}\text {-Trafikte ge- } \\
\text { çirilen süre } \\
\text {-Özel araç, } \\
\text { metro, otobüs, } \\
\text { dolmuş, bisik- } \\
\text { let veya yaya } \\
\text { olarak yapılan } \\
\text { iş yolculuğu- } \\
\text { nun yüzdesi } \\
\text {-Ulaşım hat- } \\
\text { tına veya du- } \\
\text { rağına uzak- } \\
\text { lık } \\
\text {-Araba sa- } \\
\text { hipliliği }\end{array}$ & -Suç oranı & $\begin{array}{l}\text {-kişi ba- } \\
\text { şına düşen } \\
\text { GSMH, } \\
\text { GSYH } \\
\text {-işsizlik oran } \\
\text {-işgücüne } \\
\text { katılma } \\
\text { oranı }\end{array}$ & $\begin{array}{l}\text {-Nüfus yo- } \\
\text { ğunluğu } \\
\text {-Nüfus artış } \\
\text { hızı } \\
\text {-Genç nüfus } \\
\text {-Yaşlı nüfus } \\
\text {-Engelli nü- } \\
\text { fus } \\
\text {-Okur-yazar } \\
\text { oranı } \\
\text {-Eğitim sevi- } \\
\text { yesi }\end{array}$ & $\begin{array}{l}\text {-Hava kir- } \\
\text { liliği gös- } \\
\text { tergeleri } \\
\text {-Gürültü } \\
\text { kirliliği } \\
\text {-Katı atık- } \\
\text { ların ne } \\
\text { kadarının } \\
\text { toplan- } \\
\text { dığı, dö- } \\
\text { nüştürül- } \\
\text { düğü } \\
\text {-Trafik yo- } \\
\text { ğunluğu }\end{array}$ \\
\hline \multicolumn{6}{|c|}{$\begin{array}{l}\text { Kaynak: Abbate vd. (2001), AB (2004), BİB (2008), Demirkaya (2010), Dülger Türkoğlu vd. (2008), ), Evcil Türksever ve Atalık } \\
\text { (2001), Garau ve Pavan (2018), Kamp vd.(2003), Marans ve Stimson (2011), McCrea vd.(2006), Nakanishi (2015), OECD (2017), } \\
\text { Salihoğlu ve Türkoğlu (2019) Santö ve Martins. (2007), Shoja vd.(2015), Tekeli vd. (2003), Tekeli (2009), Tesfazghi vd.(2010), } \\
\text { Ülengin vd. (2001), Yakın İnan ve Özdemir Sönmez (2019). }\end{array}$} \\
\hline
\end{tabular}




\section{Ankara Çankaya İlçesi Örneği}

Çankaya ilçesi Ankara ilinin nüfus bakımından en büyük merkez ilçesidir (Harita 1). İlçede yaklaşık 945 bin kişi (URL-1) yaşamaktadır ve ilçenin yüzölçümü 44 bin hektardır. Çankaya ilçesi ticari, finansal ve hizmet etkinliklerinin çok yoğun olduğu bir ilçedir. İlçenin gündüz nüfusu 2 milyonu geçmektedir. Çankaya'da 334 bin konut birimine karşılık 107 bin ticaret birimi bulunmaktadır (URL-2). Kamu kuruluşları, sağlık alanları, eğitim alanları, askeri alanlar, sosyal ve kültürel tesisler ve spor alanları ilçedeki diğer kullanımlardır. Çankaya ilçesinde 115'i kentsel, 9'u kırsal olmak üzere toplam 124 mahalle bulunmaktadır.

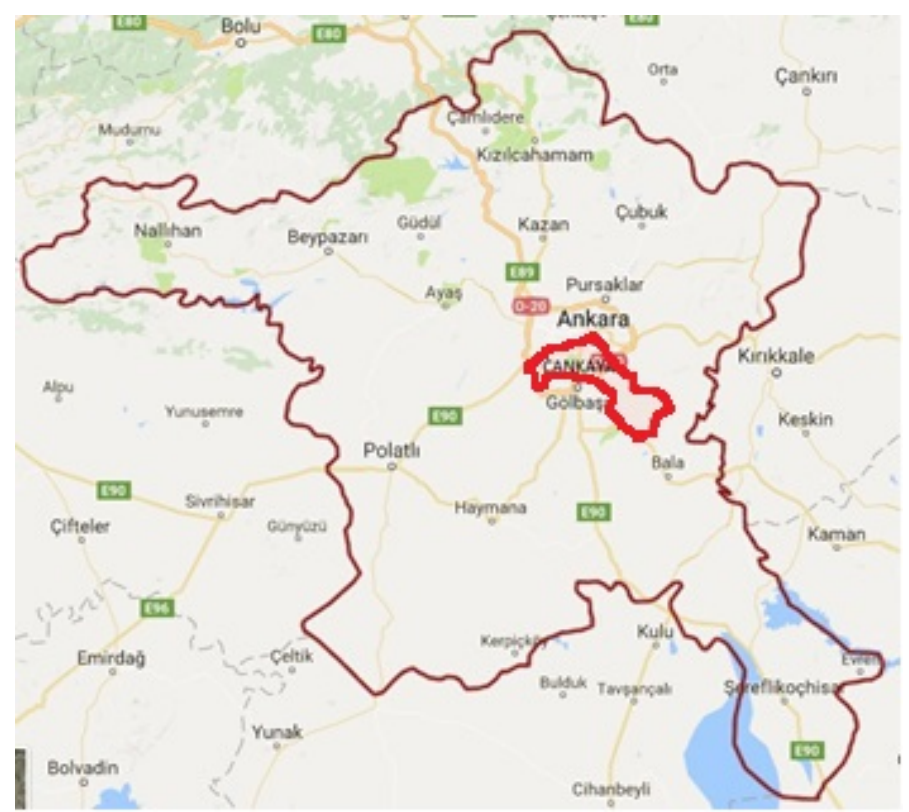

Harita 1. Çankaya İlçesinin Ankara İlindeki yeri

(Kaynak: https://www.google.com/maps/)

\section{Çalışmanın Yöntemi}

Ankara İli Çankaya İlçesi, farklı ölçeklerde kentsel mekânsal müdahalelerin ve bu müdahalelerin yaşam kalitesine etkisinin araştırılacağı örnek çalışma alanı olarak belirlenmiştir. Çalışmada Çankaya İlçesinde gerçekleştirilen imar planı değişiklikleri ile yapılan kentsel mekânsal müdahalelerin ortaya konulması amaçlanmıştır. Bu bağlamda kentte karar alma yetkisi olan farklı aktörler tarafından planlama temelinde yapılan tüm 
mekânsal müdahalelerin (plan değişiklikleri, proje önerileri) ortaya konulması ve yıllara göre değerlendirilmesi hedeflenmiştir. Bunun için öncelikle, planlama sürecine etki eden tüm aktörler yani imar planı onaylama yetkisi olan tüm kurumlar tespit edilmiştir. Arşiv çalışmaları ve mevzuat araştırmaları sonucunda çalışma alanında nazım ve uygulama imar planlarını onaylayan kurumlar belirlenmiş ve bu kurumlar yerel ve merkezi yönetimler olarak gruplandırılmıştır.

Çankaya İlçe sınırlarının 2014 yılında 6360 sayılı kanunla değişmesi sebebiyle ${ }^{5}$, Çankaya İlçesinde yapılan plan değişikliklerinin 2014-2019 yılları arasında ele alınması hedeflenmiştir. 2014-2019 yılları toplam 6 yıl boyunca merkezi ve yerel yönetimlerin onayladığ 1 tüm plan değişiklikleri tespit edilerek, plan değişiklikleri özelinde ne kapsamda bir müdahale getirildiği ve bu müdahalelerin kentsel yaşam kalitesi açısından nasıl değerlendirilebileceği tartışılmıştır.

2014-2019 yıllarında yapılan plan değişikliklerini tespit etmek için Ankara Büyükşehir Belediye Meclisi'nin resmi internet sitesinde yayınlanan 2014-2019 yılları arasında alınan tüm meclis kararları incelenerek, dökümleri yapılmıştır. Buna ek olarak planlama sürecinde yetkisi olan diğer kurumların 2014-2019 yılları arasında onayladığı tüm plan değişiklikleri, Çevre Şehircilik Bakanlığı'ndan alınan şifahi bilgiler ve Çankaya Belediyesi arşivinden elde edilen veriler ile çıarılmıştır.

2014-2019 yılları arasında onaylanan tüm plan değişikliklerinin yapıldiğı mahalleler, hangi kurumun yaptı̆̆ı, plan değişikliğinin türü ve yaşam kalitesi açısından yapılan değişikliğin kente/mahalleye etkisi değerlendirilmiştir.

\section{Bulgular}

Geçmişten günümüze planlama sürecine etki eden mekânsal planları onaylama yetkisi olan kurumlar merkezi ve yerel yönetimler olarak gruplandırılmaktadır (Tablo 3).

\footnotetext{
${ }^{5} 6360$ sayılı Ondört İlde Büyükşehir Belediyesi ve Yirmiyedi İlçe Kurulması ile Bazı Kanun ve Kanun Hükmünde Kararnamelerde Değişiklik Yapılmasına Dair Kanunun 2. Maddesinin 42. Bendine göre 'Ankara ilinde, Yenimahalle ilçesine bağlı Dodurga ve Alacaatlı Mahallelerinin çevre yolu içinde kalan kısmı ile Çayyolu, Prof. Dr. Ahmet Taner Kışlalı, Ümit, Koru, Konutkent ve Yaşamkent Mahalleleri, Çankaya ilçe sınırlarına dâhil edilerek, Çankaya Belediyesine katılmıştır.'
} 
Tablo 3. Planlama Sürecine Etki Eden Aktörler (İmar Planı Onaylama Yetkisi olan Kurumlar)

\begin{tabular}{ll}
\hline Planlama Sürecine Etki Eden Aktörler (İmar Planı Onaylama Yetkisi olan Kurumlar) \\
\hline Yerel & -Büyükşehir Belediyesi \\
Yönetimler & -İçe Belediyesi ( planları uygun görür onaylanmak üzere büyükşehir beledi- \\
& yesine gönderir.) \\
\hline Merkezi & -Çevre ve Şehircilik Bakanlığı \\
Yönetimler & -Başbakanlık Özelleştirme İdaresi Başkanlığı \\
& -Bilim Sanayi ve Teknoloji Bakanlığı \\
& -Milli Savunma Bakanlığı \\
& -TOKİ \\
& -İller Bankası \\
& -Cumhurbaşkanlığı \\
& -Kültür ve Tabiat Varlıklarını Koruma Kurulu \\
& -Bayındırlık ve İskan Bakanlığı ( Eski Planlar) \\
& -İmar İdare Heyeti (Eski Planlar) \\
& -İl İdare Kurulu (Eski Planlar) \\
& -Özel Çevre Koruma Kurumu Başkanlığı (Eski Planlar)
\end{tabular}

Çalışmada kentsel mekânsal müdahale kapsamında gerçekleştirilen mekansal planlar ve yapılan plan değişikliklerinin yaşam kalitesine etkileri değerlendirilmektedir. Analizler sonucunda Çankaya ilçesinde 20142019 yıllarında merkezi ve yerel yönetimlerin onayladığ 1 toplam 1473 adet plan değişikliği kararı alındığı tespit edilmiştir. Analiz yapılan 6 yıl içinde yerel yönetimlerin onayladığı 1382, merkezi yönetimlerin onayladı̆̆ 91 adet kararın olduğu görülmektedir (Tablo 4).

Tablo 4. 2014-2019 yılları yerel ve merkezi yönetimin onayladığı toplam karar sayıları

$$
\text { Sayı } \%
$$

\begin{tabular}{lrr}
\hline Yerel & 1382 & 93,8 \\
\hline Merkezi & 91 & 6,2 \\
\hline Toplam & 1473 & 100,0 \\
\hline
\end{tabular}

2014-2019 yılları arasında merkezi ve yerel yönetimlerin onayladığı tüm kararlar karar türlerine göre sınıflandırılmıştır. Onaylanan toplam 1473 kararın 661 adedi herhangi bir müdahale içermeyen plan değişiklikleri ve kararları kapsadığı için çalışmada 'değişiklik yok' olarak tanımlanmıştır. Geri kalan 812 adet plan değişikliği kararı ise yalnız kullanım kararı değişikliğii, yalnız yapılaşma koşulu değişikliği ve hem kulanım kararı hem de yapılaşma koşulu değişikliği bir arada olan kararlar şeklinde gruplanmıştır. Plan değişikliklerinin 182 adedi yalnız kullanım kararı değişikliği, 226 adedi yapılaşma koşulu değişikliği ve 404 adedi hem kulanım kararı hem yapılaşma koşulu değişikliklerini kapsamaktadır (Tablo 5). 
Tablo 5. 2014-2019 yıllarında yerel yönetimlerin ve merkezi yönetimlerin onayladı̆̆ plan değişiklerinin karar türleri ayrıntısı

\begin{tabular}{llrr}
\hline $\begin{array}{l}\text { Kullanım ve yapılaşma } \\
\text { değişikliği }\end{array}$ & & Sayı & \% \\
\hline $\begin{array}{l}\text { Yapılaşma koşulu } \\
\text { değişikliği }\end{array}$ & & 404 & 27,4 \\
\hline $\begin{array}{l}\text { Kullanım kararı } \\
\text { değişikliği }\end{array}$ & & 226 & 15,3 \\
\hline Değişiklik Yok & $\begin{array}{l}\text { Değişiklik içermeyen karar türü tespit } \\
\text { edilemeyen }\end{array}$ & 182 & 12,4 \\
\cline { 2 - 4 } & İtirazın reddi & 132 & 9,0 \\
\cline { 2 - 4 } & Trafo alanı & 226 & 15,3 \\
\cline { 2 - 4 } & Kullanım-yapılaşma değişikliği RED & 122 & 8,3 \\
\cline { 2 - 4 } & Yapılaşma koşulu değişikliği RED & 58 & 3,9 \\
\cline { 2 - 4 } & Kullanım kararı değişikliği RED & 51 & 3,5 \\
\cline { 2 - 4 } & Planlama genel kararı & 28 & 1,9 \\
\cline { 2 - 4 } & Sinır ilanı & 19 & 1,7 \\
\hline Toplam & & 1473 & 1,3 \\
\hline
\end{tabular}

Çalışmada 'değişiklik yok' olarak belirlenen 661 adet karar; planlamaya ilişkin planlama genel kararları, trafo alanları plan değişiklikleri, belediye meclisince kabul edilmeyen red edilen kullanım kararı içeren plan değişikliği, belediye meclisince kabul edilmeyen red edilen yapılaşma koşulu değişikliği içeren plan değişikliği, belediye meclisince kabul edilmeyen red edilen kullanım ve yapılaşma koşulu değişikliği içeren plan değişiklikleri, plan değişikliklerine yapılan itirazların reddine ilişkin kararları, sınır ilanları kararlarını ve değişiklik içermeyen karar türü tespit edilemeyen kararları içermektedir. Bu kararlar mekânsal olarak müdahale içeren kararlar olmadığından, çalışmanın ilerleyen aşamasında yaşam kalitesine etkisi üzerinden değerlendirmeye alınmamıştır. Yaşam kalitesine etki değerlendirmesinde, toplam 812 adet müdahale içeren plan değişikliği kararının analizleri yapılmıştır.

Merkezi ve yerel yönetimler tarafından onaylanan plan değişikliği kararları analizine göre, plan değişikliklerinin \%22,4'ü kullanım kararı değişiklikleri, \%27,8'i yapılaşma koşulu değişikliği ve \%49,8'i kullanım kararı ve yapılaşma koşulu değişikliğini içermektedir (Grafik 1). 


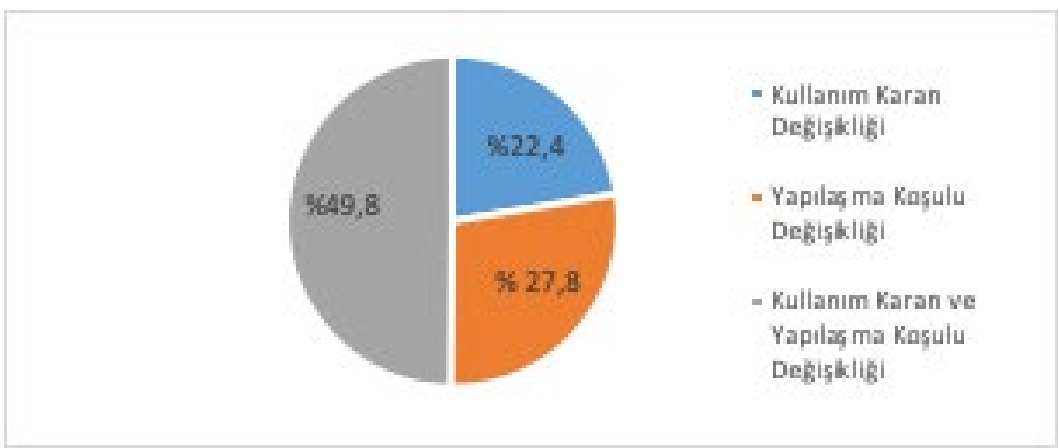

Grafik 1. Plan değişikliklerine ilişkin karar türleri

Tablo 6'da plan değişikliği karar türleri çalışma alanı kapsamına alınan tüm yıllar için gösterilmiştir. En fazla plan değişikliği 2016 yılında (176 adet, \%21,7) yapılmıştır. 2016 yılını 2014 yılı (162 adet, \%20) takip etmektedir.

Tablo 6. 2014-2019 yılları arasında gerçekleşen plan değişikliklerine ilişkin karar türleri

\begin{tabular}{|c|c|c|c|c|c|c|c|c|}
\hline & & 2014 & 2015 & 2016 & 2017 & 2018 & 2019 & Toplam \\
\hline \multirow{2}{*}{$\begin{array}{l}\text { Kullanım kararı } \\
\text { değişikliği }\end{array}$} & Say1 & 42 & 20 & 41 & 32 & 33 & 14 & 182 \\
\hline & $\%$ & 23,1 & 11,0 & 22,5 & 17,6 & 18,1 & 7,7 & 100 \\
\hline \multirow{2}{*}{$\begin{array}{l}\text { Yapılaşma } \\
\text { koşulu } \\
\text { değişikliği }\end{array}$} & Sayı & 42 & 31 & 74 & 34 & 33 & 12 & 226 \\
\hline & $\%$ & 18,6 & 13,7 & 32,7 & 15,0 & 14,6 & 5,3 & 100 \\
\hline \multirow{2}{*}{$\begin{array}{l}\text { Kullanım ve } \\
\text { yapılaşma } \\
\text { koşulu } \\
\text { değişikliği }\end{array}$} & Sayı & 78 & 92 & 61 & 71 & 58 & 44 & 404 \\
\hline & $\%$ & 19,3 & 22,8 & 15,1 & 17,6 & 14,4 & 10,9 & 100 \\
\hline \multirow[t]{2}{*}{ Toplam } & Sayı & 162 & 143 & 176 & 137 & 124 & 70 & 812 \\
\hline & $\%$ & 20,0 & 17,6 & 21,7 & 16,9 & 15,3 & 8,6 & 100 \\
\hline
\end{tabular}

Onaylanan plan değişikliklerinin hangi aktörler tarafından yapıldığına bakıldığında, plan değişikliklerinin \%89,7'si yerel yönetimlerce, \%10,3’ü ise merkezi yönetimlerce onaylanmıştır. Bu durumda, onaylanan plan değişikliklerinin önemli bir kısmının yerel yönetimlerce yapıldığı sonucu ç1karllabilmektedir (Tablo 7).

2014-2019 yılları arasında onaylanan plan değişikliklerinin karar türlerine göre hangi aktörler tarafından onaylandığına bakıldığında, toplam 812 adet plan değişikliğinin 728 adedi Ankara Büyükşehir Belediyesi tarafından, 75 adedi Çevre ve Şehircilik Bakanlığı, 3 adedi Cumhurbaşkanlığı, 3 adedi Bilim Sanayi ve Teknoloji Bakanlığı, 2 adedi Başbakanlık 
Özelleştirme İdaresi Başkanlığı, 1 adedi ise TOKİ tarafından onaylanan plan değişiklikleridir.

Tablo 7. Yerel ve merkezi yönetimlerce onaylanan plan değişikliklerinin karar türleri

\begin{tabular}{llrrr}
\hline & & Yerel & Merkezi & Toplam \\
\hline Kullanım kararı değişikliği & Sayı & 171 & 11 & 182 \\
\cline { 2 - 5 } & $\%$ & 94,0 & 6,0 & 100,0 \\
\hline Yapılaşma koşulu değişikliği & Sayı & 213 & 13 & 226 \\
\cline { 2 - 5 } & $\%$ & 94,2 & 5,8 & 100,0 \\
\hline Kullanım ve yapılaşma koşulu değişikliği & Sayı & 344 & 60 & 404 \\
\cline { 2 - 5 } & $\%$ & 85,1 & 14,9 & 100,0 \\
\hline Toplam & Sayı & 728 & 84 & 812 \\
\cline { 2 - 5 } & $\%$ & 89,7 & 10,3 & 100,0 \\
\hline
\end{tabular}

Tablo 8'de en fazla plan değişikliğinin Ankara Büyükşehir Belediyesi tarafından kullanım ve yapılaşma koşulu değişikliğine ilişkin yapılan müdahaleler olduğu görülmektedir. İkinci en fazla plan değişikliği ise yine Ankara Büyükşehir Belediyesi tarafından yapılaşma koşulu değişikliğine ilişkin yapılan müdahalelerdir.

Tablo 8. Yerel ve merkezi yönetim kurumlarının onayladığı plan değişikliklerinin karar türleri

\begin{tabular}{|c|c|c|c|c|c|c|c|c|}
\hline & & 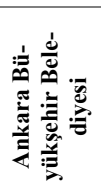 & 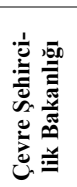 & 志䮍 & 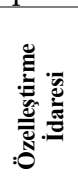 & 긍 & 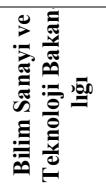 & $\frac{\Xi}{\text { है }}$ \\
\hline \multirow{2}{*}{$\begin{array}{l}\text { Kullanım kararı } \\
\text { değişikliği }\end{array}$} & Say1 & 171 & 11 & 0 & 0 & 0 & 0 & 182 \\
\hline & $\%$ & 94,0 & 6,0 & 0 & 0 & 0 & 0 & 100 \\
\hline \multirow{2}{*}{$\begin{array}{l}\text { Yapılaşma ko- } \\
\text { şulu değişikliği }\end{array}$} & Say1 & 213 & 13 & 0 & 0 & 0 & 0 & 226 \\
\hline & $\%$ & 94,2 & 5,8 & 0 & 0 & 0 & 0 & 100 \\
\hline \multirow{2}{*}{$\begin{array}{l}\text { Kullanım ve ya- } \\
\text { pılaşma koşulu } \\
\text { değişikliği }\end{array}$} & Sayı & 344 & 51 & 3 & 2 & 1 & 3 & 404 \\
\hline & $\%$ & 85,1 & 12,6 & 0,7 & 0,5 & 0,2 & 0,7 & 100 \\
\hline \multirow[t]{2}{*}{ Toplam } & Sayı & 728 & 75 & 3 & 2 & 1 & 3 & 812 \\
\hline & $\%$ & 89,7 & 9,2 & 0,4 & 0,2 & 0,1 & 0,4 & 100 \\
\hline
\end{tabular}

2014-2019 yıllarında yapılan plan değişikliği kararları yaşam kalitesine etkileri değerlendirilmiştir. Değerlendirme yapılırken planlama ilke ve esaslarına uygunluğu açısından kararlar olumlu, olumsuz ve etkisiz (nötr) olarak gruplandırılmıştır. İçeriği anlaşılamayan kararlar ise kararsız olarak belirlenmiştir (Tablo 9). 
Tablo 9. Kentsel Müdahale İçeren Plan Değişikliklerinin Kentsel Yaşam Kalitesi Değerlendirmesi

\author{
Plan Değişikliği Kararların Niteliği
}

\section{Plan Değişikliği Kararı- \\ nın Kentsel Yaşam \\ Kalitesine Etkisine \\ İlişkin Değerlendirme \\ Yaşam Kalitesi Göstergesi}

Konut alanlarının sosyal donatı alanlarına dönüştürülmesi

Ticaret alanlarından özel sosyal donatı alanları yaratılması (donatı alanlarının artması daha çok kişinin sosyal erişimine açık olduğu için)

Sosyal donatı alanlarında emsal artışı (Mahalle, yerleşme özelinde sosyal donatı standartlarına bakılarak ihtiyaç olup olmamasına ve yerleşme dokusunu nasıl etkilediğine göre değerlendirme yapılmıştır.)

Konut alanlarının sosyal donatı alanlarına dönüşürken emsal artışı olması (yerleşim dokusunun bozulması, artan yoğunluk nedeniyle başta trafik olmak üzere altyapı sorunlarının oluşması)

Sosyal donatı alanlarının özele çevrilmesi (kamusal bir hizmetin özelleşmesi hizmetten yararlanacak kesimin daralmasina neden oluyor)

Konut alanlarında emsal artışı (yapılaşma ve kullanım yoğunluğunu artırarak kentsel açık alanların oranını düşürüyor, altyapı sunumunu olumsuz etkiliyor)

Açık yeşil alanların konut, ticaret alanına dönüştürülmesi (yapılaşma ve kullanım yoğunluğunu artırarak kentsel açık alanların oranını düşürüyor, altyapı sunumunu olumsuz etkiliyor)

Park alanlarının Rekreasyon alanına dönüştürülmesi (genellikle emsal verilerek yeşil alan içinde kafe, restoran, büfe gibi kullanımlarla yapılaşma hakkı veriliyor) Konut alanının turizme yani otele dönüştürülmesi (konut kullanımına göre tasarlanmış alanlarda konut dışı kullanımların gelişmesi üstyapı ve altyapı sorunları oluşturur, sessiz sakin konut ortamı, komşuluk ilişkileri, otopark, trafik yoğunluğu, vs.)

Sosyal donatı alanının başka bir sosyal donatı alanına dönüştürülmesi

Mevcut plandaki kullanımdan farklı bir kullanımın planla yasallaştırılması (Örn: Planda konut alanı olarak gözüken bir yerin plan değişikliği ile sağlık alanına dönüştürülmesi ve zaten yapılmış olan sağlık tesisinin -fiili durumun- yasallaşması)

Planlama ilke ve kararlarını değiştirmeyecek plan notu ilaveleri
Yerleşme-Mekan Kalitesi (Sosyal Donatı Alanları yeterliliği) Yerleşme - Mekan Kalitesi (Sosyal Donatı Alanları yeterliliği)

Olumlu

Yerleşme - Mekan Kalitesi (Sosyal Donatı Alanları dağılımı ve yeterliliği)

Yerleşme - Mekan Kalitesi (Sosyal Donatı Alanları yeterliliği)

Yerleşme - Mekan Kalitesi (Sosyal Donatı Alanlarına erişebilirlik)

Yerleşme - Mekan Kalitesi (Konut Alanları yeterliliği)

Olumsuz

Yerleşme - Mekan Kalitesi (Sosyal Donatı Alanları ve Yeşil alan yeterliliği)

Yerleşme- Mekan Kalitesi (Sosyal Donatı Alanları yeterliliğiYeşil alan yeterliliği)

Yerleşme - Mekan Kalitesi

Yapılan analizler sonucunda onaylanan toplam 812 adet plan değişikliğinin \%70,1'i olumsuz, \%19,1'i nötr, \%10,1'i olumlu ve \%0,7’si kararsız olarak tespit edilmiştir (Tablo 10). 
Tablo 10. 2014-2019 yıllarında onaylanan plan değişiklerinin yaşam kalitesi değerlendirmesi

\begin{tabular}{lrrrrrr}
\hline & & Olumsuz & Olumlu & Nötr & Kararsız & Toplam \\
\hline $\begin{array}{l}\text { Kullanım kararı } \\
\text { değişikliği }\end{array}$ & Sayı & 111 & 18 & 51 & 2 & 182 \\
\hline & $\%$ & 61,0 & 9,9 & 28,0 & 1,1 & 100 \\
\hline $\begin{array}{l}\text { Yapılaşma koşulu } \\
\text { değişikliği }\end{array}$ & Sayı & 144 & 28 & 54 & 0 & 226 \\
\hline & $\%$ & 63,7 & 12,4 & 23,9 & 0 & 100 \\
\hline $\begin{array}{l}\text { Kullanım ve yapı- } \\
\text { laşma koşulu deği- } \\
\text { şikliği }\end{array}$ & Sayı & 314 & 36 & 50 & 4 & 404 \\
\hline & $\%$ & 77,7 & 8,9 & 12,4 & 1,0 & 100 \\
\hline Toplam & Sayı & 569 & 82 & 155 & 6 & 812 \\
\hline & $\%$ & 70,1 & 10,1 & 19,1 & 0,7 & 100 \\
\hline
\end{tabular}

Yıllara göre onaylanan plan değişiklerinin yaşam kalitesi değerlendirmesi incelemesi sonucu en fazla olumsuz plan değişikliği yapılan yıl 2016 yılıdır. En fazla olumlu plan değişikliği yapılan yıl ise 2018 yılıdır (Grafik 2).

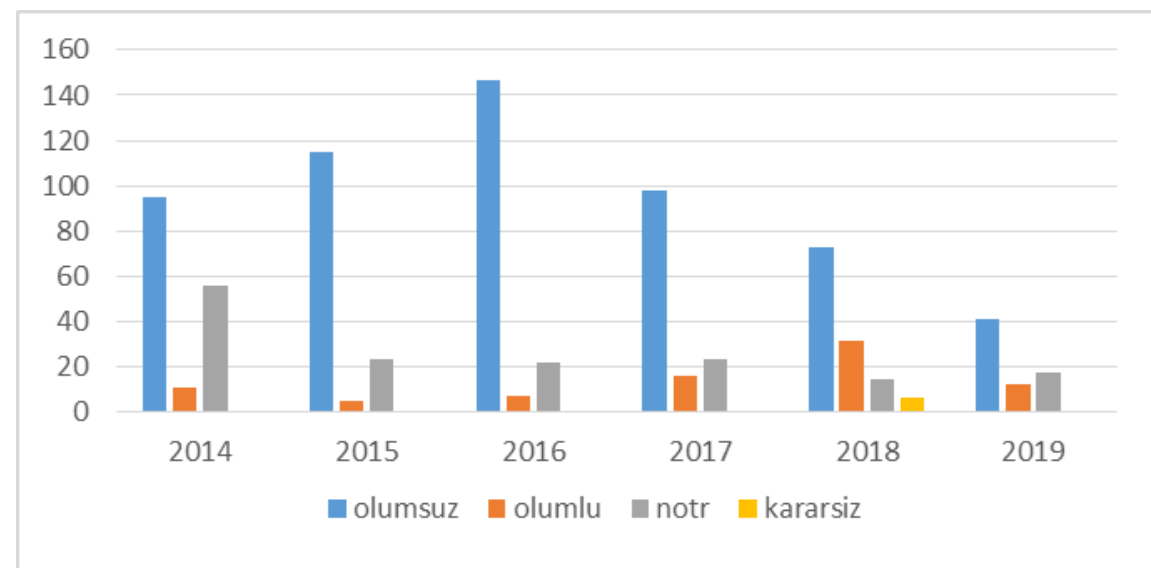

Grafik 2. 2014-2019 yılları arasında onaylanan plan değişiklerinin yaşam kalitesi üzerinde etkisinin değerlendirmesi

Çankaya İlçesinde toplamda 124 mahalle bulunmaktadır. Yapılan çalışmada 2014-2019 yıllarında 88 (\%71) mahallede müdahale içeren plan değişikliğinin onaylandığı görülmektedir. Tablo 11'de yapılan plan değişikliklerinin yarısından fazlasının (\%55,7) ilk 10'unda gerçekleştiği görülmektedir. Analiz sonucunda en fazla plan değişikliği yapılan mahalle 
Beytepe Mahallesi olarak tespit edilmiştir. Beytepe Mahallesini; Alacaatlı, Yukarı Dikmen, Çayyolu, Mustafa Kemal, Kızılırmak, Dodurga, Mutlukent, Birlik, Keklikpınarı Mahalleleri takip etmektedir.

Tablo 11. Mahallelerde onaylanan plan değişikliklerinin karar türleri

\begin{tabular}{lllllll}
\hline Mahalle Adı & $\begin{array}{l}\text { Kullanım } \\
\text { kararı deği- } \\
\text { şikliği }\end{array}$ & $\begin{array}{l}\text { Yapılaşma } \\
\text { koşulu de- } \\
\text { ğişikliği }\end{array}$ & $\begin{array}{l}\text { Kullanım ve } \\
\text { yapılaşma } \\
\text { değişikliği }\end{array}$ & Toplam & & \\
\hline $\mathbf{1}$ & Beytepe & 20 & 30 & 75 & 125 & 15,4 \\
\hline $\mathbf{2}$ & Alacaatl & 19 & 27 & 54 & 100 & 12,3 \\
\hline $\mathbf{3}$ & Yukarı Dikmen & 7 & 10 & 22 & 39 & 4,8 \\
\hline $\mathbf{4}$ & Çayyolu & 10 & 7 & 19 & 36 & 4,4 \\
\hline $\mathbf{5}$ & Mustafa Kemal & 7 & 10 & 19 & 36 & 4,4 \\
\hline $\mathbf{6}$ & Kizılırmak & 6 & 14 & 10 & 30 & 3,7 \\
\hline $\mathbf{7}$ & Dodurga & 4 & 11 & 9 & 24 & 3,0 \\
\hline $\mathbf{8}$ & Mutlukent & 10 & 4 & 10 & 24 & 3,0 \\
\hline $\mathbf{9}$ & Birlik & 4 & 8 & 8 & 20 & 2,5 \\
\hline $\mathbf{1 0}$ & Keklikpınarı & 3 & 4 & 11 & 18 & 2,2 \\
\hline & Toplam & & & & 452 & 55,7 \\
\hline & Diğer (78 mahalle) & & & & 360 & 44,3 \\
\hline
\end{tabular}

Mahallelerde onaylanan plan değişikliklerinin karar türleri incelendiğinde, en fazla plan değişikliği onaylanan Beytepe Mahallesinde hem kullanım hem de yapılaşma koşulu değişikliği yapılan 75 adet plan değişikliği tespit edilmiştir.

Mahallelerde onaylanan plan değişikliklerinin yaşam kalitesi değerlendirmesi analizlerine bakıldığında, Beytepe Mahallesinde onaylanan plan değişikliklerinin \%83,2'si olumsuz, \%3,2'si olumlu olarak değerlendirilmiştir. İkinci en fazla plan değişikliği onaylanan Alacaatlı Mahallesinde ise, onaylanan plan değişikliklerinin \%76'sı olumsuz, \%11'i olumlu olarak değerlendirilmiştir (Tablo 12).

Grafik 3'de ise en fazla plan değişikliği onaylanan mahallelerde yıllara göre plan değişikliği sayıları ortaya konmuştur. Buna göre mahallelere göre en fazla plan değişikliği yapılan yıllar farklılaşmaktadır. Örneğin Beytepe Mahallesi'nde en fazla plan değişikliği 2016 yılında onaylanmasına rağmen Alacaatı'ı'da en fazla plan değişikliği 2014 yılında yapılmıştır. 
Tablo 12. Mahallelerde onaylanan plan değişikliklerinin yaşam kalitesi değerlendirmesi

\begin{tabular}{cccccccc}
\hline & Mahalle kodu & & olumsuz & olumlu & nötr & $\begin{array}{c}\text { karar- } \\
\text { s1z }\end{array}$ & toplam \\
\hline $\mathbf{1}$ & Beytepe & Say1 & 104 & 4 & 17 & 0 & 125 \\
\hline & & $\%$ & 83,2 & 3,2 & 13,6 & 0,0 & 100,0 \\
\hline $\mathbf{2}$ & Alacaatlı & Say1 & 76 & 11 & 11 & 2 & 100 \\
\hline & & $\%$ & 76,0 & 11,0 & 11,0 & 2,0 & 100,0 \\
\hline $\mathbf{3}$ & Yukarı Dikmen & Say1 & 33 & 3 & 3 & 0 & 39 \\
\hline & & $\%$ & 84,6 & 7,7 & 7,7 & 0,0 & 100,0 \\
\hline $\mathbf{4}$ & Çayyolu & Say1 & 23 & 5 & 7 & 1 & 36 \\
\hline & & $\%$ & 63,9 & 13,9 & 19,4 & 2,8 & 100,0 \\
\hline $\mathbf{5}$ & Mustafa Kemal & Say1 & 24 & 2 & 10 & 0 & 36 \\
\hline & & $\%$ & 66,7 & 5,6 & 27,8 & 0,0 & 100,0 \\
\hline $\mathbf{6}$ & Kizllirmak & Say1 & 26 & 1 & 3 & 0 & 30 \\
\hline & & $\%$ & 86,7 & 3,3 & 10,0 & 0,0 & 100,0 \\
\hline $\mathbf{7}$ & Dodurga & Say1 & 16 & 5 & 3 & 0 & 24 \\
\hline & & $\%$ & 66,7 & 20,8 & 12,5 & 0,0 & 100,0 \\
\hline $\mathbf{8}$ & Mutlukent & Say1 & 16 & 1 & 7 & 0 & 24 \\
\hline & & $\%$ & 66,7 & 4,1 & 29,1 & 0,0 & 100,0 \\
\hline $\mathbf{9}$ & Birlik & Say1 & 13 & 3 & 4 & 0 & 20 \\
\hline & & $\%$ & 65,0 & 15,0 & 20,0 & 0,0 & 100,0 \\
\hline $\mathbf{1 0}$ & Keklikpinar1 & Say1 & 11 & 2 & 5 & 0 & 18 \\
\hline & & $\%$ & 61,1 & 11,1 & 27,8 & 0,0 & 100,0 \\
\hline & Toplam & Say1 & $\mathbf{5 6 9}$ & $\mathbf{8 2}$ & $\mathbf{1 5 5}$ & $\mathbf{6}$ & $\mathbf{8 1 2}$ \\
\hline & & $\%$ & $\mathbf{7 0 , 1}$ & $\mathbf{1 0 , 1}$ & $\mathbf{1 9 , 1}$ & $\mathbf{0 , 7}$ & $\mathbf{1 0 0 , 0}$ \\
\hline
\end{tabular}

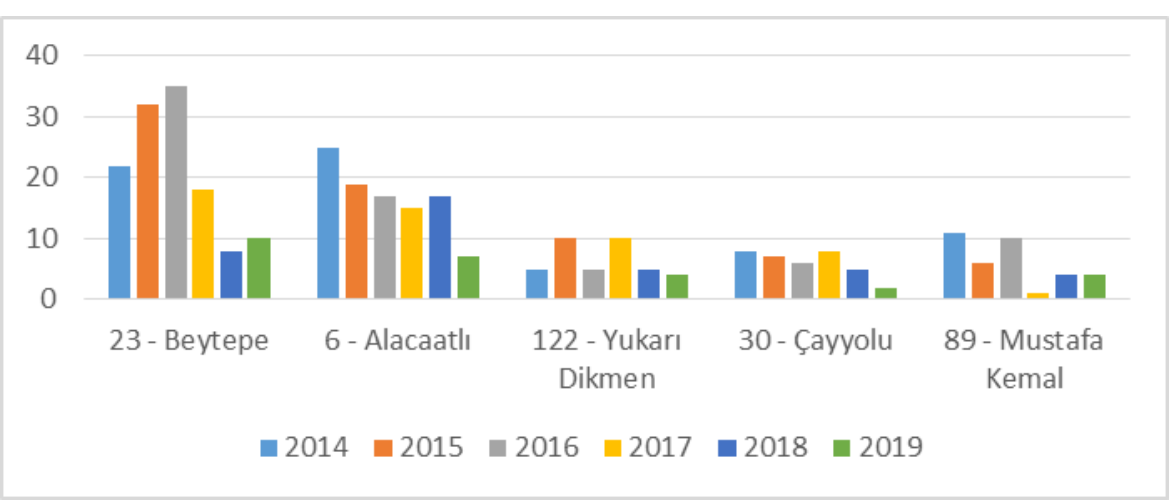

Grafik 3. Yıllara göre mahallelerde onaylanan plan değişikliği sayıları

Harita 2' de de 2014-2019 yıllarında Çankaya İlçesinde yerel ve merkezi yönetimlerce onaylanan plan değişikliklerinin mahallelere göre dağılımı gösterilmektedir. En fazla plan değişikliği yapılan Beytepe Mahallesi koyu kırmızı ile belirtilmiştir. Koyu kırmızdan açık kırmızıya doğru mahallelerde yapılan plan değişikliği sayısı azalmaktadır. 


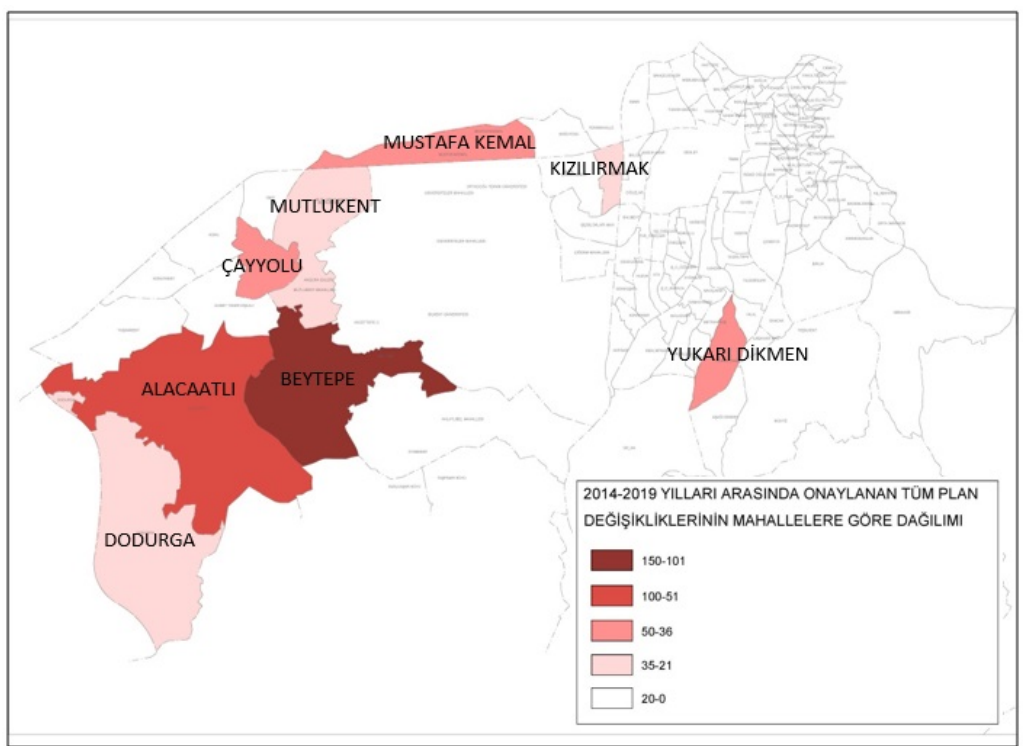

Harita 2. 2014-2019 yıllarında onaylanan tüm plan değişikliklerinin mahallelere göre dağılımı

Plan değişiklerinin mahallelere göre dağılım haritasının yorumlanmasında Çankaya İlçesindeki mahallelerin yapılaşma durumları incelenmiştir. Google haritalardan mahallelerdeki doluluk boşluk oranlarına bakılarak tamamen yapılaşmış, yapılaşması devam eden ve yeni yapılaşan mahalleler tespit edilmiştir. Bu kapsamda 2014-2019 yılında en fazla plan değişikliği yapılan mahallelerin yeni yapılaşan ve yapılaşması hala devam eden mahalleler olduğu anlaşılmaktadır.

Ankara Çankaya İlçesinde mekânsal plan değişikliklerinin kentsel yaşam kalitesine etkisi çalışması genel olarak değerlendirildiğinde; kentsel yaşam kalitesine etki eden kentsel müdahale içeren plan değişiklikleri; aktörlerin niteliğine göre en fazla, planların uygulamasındaki sorumlu temel kurum olarak görülen Ankara Büyükşehir Belediyesi tarafından; yıllara göre en fazla, konut üretim talebinde patlama yaşanan yıllardan biri olan 2016 yılında; mahallelere göre en fazla, yapılaşmasını henüz tamamlamamış, rantın ve spekülatif eğilimlerin yoğunlaştığı Ankara'nın güneybatı eksenindeki Beytepe, Alacaatlı Mahallelerinde; karar türüne göre en fazla, hem yapılaşma koşulu değişikliği hem de kullanım kararı değişikliği kararlarının; plan değişikliği kararlarının yaşam kalitesine etkisi açısından ise en fazla, olumsuz kararın onaylandığı tespit edilmiştir. Bu durumda, imar planlama sürecinin devam ettiği yeni gelişen mahallelerde kullanım ve yapılaşma koşulları değişikliği getiren ve ağırlıklı olarak yapılaşma 
emsalini artıracak nitelikteki parsel bazlı düzenlemelerin yaşam kalitesini olumsuz etkilediği yorumunu çıkarmak çok da yanlış olmayacaktır.

\section{Tartışma ve Sonuç}

Bu çalışmada, kent planlama pratiğindeki kentsel mekânsal müdahaleler ile yaşam kalitesi bir arada irdelenerek, kuramsal ve uygulama açısından planlama disiplinine katkı sunulması hedeflenmiştir. Yapılan araştırmada, mekânsal planlara yönelik karar alma yetkisi olan farklı aktörlerce gerçekleştirilen müdahalelerin sayıca çok fazla olduğu ve büyük çoğunluğunun kentsel yaşam kalitesine etkisinin olumsuz olduğu tespit edilmiştir.

Çalışmada plan değişikliklerinin kentsel yaşam kalitesine etkisinin olumsuz olarak tespit edildiği plan kararları konut ve ticaret alanlarında emsal artışları, sosyal donatı alanlarının azalması, kamusal alanların özel kullanım alanlarına dönüştürülmesi, konut alanı olarak planlanan alanların ticaret, turizm alanlarına dönüştürülmesi gibi sermaye birikim süreçleri ile ilişkili kentsel rant odaklı konuları içerdiği görülmektedir. Dolayısıyla çalışma alanında alınan olumsuz olarak nitelendirilen plan kararlarının büyük çoğunluğunun liberal politikalar ve küreselleşme sürecinin getirdiği kentsel yaşam alanlarına yapılan ekonomik ve politik müdahaleleri içerdiği anlaşılmaktadır.

Buna ek olarak kentlerimizde ve çalışma alanında mekânsal planlara imar planı değişiklikleri ile sayıca fazla müdahale yapılması mevcut planın ana kararları ve bütünlüğünü bozduğu, bu durumunda kentsel yaşam alanlarımızın yaşam kalitesini düşürdüğü görülmektedir.

Diğer yandan, çalışma kapsamında plan değişiklikleri ile yapılan kentsel müdahalelerin kentsel yaşam kalitesine etkisine bakarken plan değişikliği kararlarında uluslararası ve ulusal yazından çıkarılan temel yaşam kalitesini artırmaya yönelik göstergelerin birçoğunun kentsel mekânsal müdahale kararlarına yansımadığı görülmektedir. Özellikle çevre ve sosyal konulardaki yaşam kalitesinin artırılmasına yönelik göstergelerin plan değişikliği kararlarında yer almadığı gözlenmektedir.

Sonuç olarak, kentsel mekanın biçimlenmesi ve yeniden üretilmesi sürecinde Keskinok'un (1998) da ileri sürdügü gibi her zaman "işlevselci bir bakış açısı” olamadığı, mekânsal müdahalelerin çoğu zaman sermaye birikim süreçleriyle ilişkilendirildiği açıkça görülmektedir. Alan çalışması kentsel müdahalelerin ağırlıklı olarak kentsel yaşam kalitesini artırmaya 
değil, kentsel arazi üzerindeki ranta ilişkin taleplerin karşılamasına yönelik olduğunu göstermiştir. Bu bağlamda, kentsel müdahalelerin ekonomi ve politikadan bağımsız biçimlenemediği, yeni liberal politikalar ve küreselleşme sürecinin kentsel yaşam alanlarına yapılan müdahaleleri olumsuz bir şekilde etkilediği ve bu durumun kentsel yaşam kalitesini düşürdüğü gözlenmektedir (Smith, 2002). Böylesi bir müdahale süreci, yapılan mekânsal planların etkinliğinin sorgulanması ve müdahalelerin amaçlarının tartışılması gerektiğini ortaya koymaktadır. Bu da bizi kentsel mekanın şekillenmesindeki eylemlerin, ihtiyaçlar doğrultusunda nasıl gerçekleştirilebileceğiyle ilişkili sürecin farklı yaklaşımlarla kurgulanmasına yöneltmektedir. Kentsel müdahaleler konusunda kararlar verilirken kat1lımcı ve kapsayıcı süreçlerin işletilmesi, kentlilerin mekânsal gereksinimlerinin uygulamalara yansıması açısından önemlidir. Ancak böyle bir süreç tasarımı ile kentlilerin yaşam ve mekan kalitesi beklentilerinin kentsel müdahalelere yansıması olanaklı hale gelebilecektir. Sonuç olarak, yaşam kalitesini artırmaya yönelik başarılı ve etkili kentsel politikaların oluşturulması, ancak kentte yaşayanları gözeten politikalar ve uygulamalarla gerçekleştirilebilecektir 


\section{Extended Abstract}

\section{The Effects of Spatial Plan Revisions on Urban Quality of Life: The Case of Ankara Çankaya}

İrem Akkaya Büyükcivelek
ORCID: 0000-0003-2840-0578

\author{
Çiğdem Varol \\ ORCID: 0000-0002-2432-5745
}

The increase in urban population, increases the demand for urban services as well. In order to provide these services, spatial interventions have been designed and realized in cities. Administrators, decision makers and professionals act to meet this demand and aim to increase the quality of life for urban dwellers. Despite this positive approach towards meeting the demand and increasing the quality of life, it becomes rather common to observe that most interventions end up in creating unlivable spaces.

The study aims to reveal the effect of urban spatial interventions on the quality of life of the citizens. The study proceeds through two different theoretical approaches. The first discusses the relationship between urbanization and urban interventions as an important component of the urbanization process. The second approach discusses the quality of life concept and urban quality of life.

Every urban intervention can be considered as a part of the urbanization process. In the debates on urbanization processes, authors such as Lefebvre (2007), Castells (1997), Harvey (1985) and Soja (1980) deal with the development processes of cities by creating the relationships with the political economy. In this relationship, the state (together with the urban planning institution), individuals, economic classes and politics in general play important roles. The common feature of these political economic studies is that they focus on the mode of space production of capitalist political economy and the negativities that arise from it.

The scope of quality of life concept is multidimensional. The concept is handled in different ways through various disciplines. Quality of life, in general, con- 
sists of the environmental conditions and individuals' interaction with the environment. In these researches, the environmental conditions are defined according to air and water pollution, comfort conditions of the house, etc. Besides, individual features are discussed under the headings of health status, education level, etc. (Pacione, 1986). Some concepts such as life satisfaction and well-being are also used within the concept of quality of life. The first study on the impact of the urban environment on the quality of life was conducted by Harvey Perloff in 1969. Perloff (1969) reveals that the quality of life of people in urban settlements is determined by the interaction of natural and man-made environment. Quality of life differs for every society and every person living in that society. In addition, it also differs according to the conditions within the same society.

In the study, indicators used by different authors about the quality of urban life, are classified under four main groups: environmental, social, economic and spatial. However, due to limitations on data availability, only two of the groups, the social and spatial have been used in the study for the evaluation. Under the social indicators; education, culture, health and green space facilities, and under the spatial indicators transportation, accessibility and infrastructure are considered.

Çankaya District of Ankara has been determined as the sample study area where urban spatial interventions at different scales and the positive and negative effects of these interventions on quality of life have been investigated. In the study, it is aimed to reveal and evaluate urban spatial interventions through spatial plan revisions by different decision-makers in Çankaya District. For this, first, all the actors affecting the planning process, that is, all the institutions that have the authority to approve spatial development plans have been determined. Then, during the years 2014-2019, all the spatial plan revisions approved by the central and local governments have been analyzed, and the scope of the intervention and their impact on urban quality of life have been discussed. In the analysis of plan revisions between 2014-2019, all the council decisions published on the official website of the Ankara Metropolitan Municipality Council have been evaluated. In addition, the plan revisions approved by other institutions like the Ministry of Environment and Urbanization have been considered as well. Data set has further developed with the documents from the archive of Çankaya Municipality.

According to findings, Ankara Metropolitan Municipality has been found out as the principal institution responsible for the revisions of the plans. Most of the plan revisions were in 2016, which was one of the booming years in the demand for housing production. Beytepe and Alacaatlı Neighborhoods on the southwest axis of Ankara, where the construction has not been completed yet and where rent and speculative tendencies have been concentrated have been found to be 
the ones where plan changes appeared the most. Revision decisions mainly include both the change of construction conditions and land-use decision changes. Based on the evaluation of plan revision decisions, it is seen that decisions that negatively affect the quality of life conditions are more than positive ones. In sum, it can be concluded that parcel in the newly developing neighborhoods where the spatial arrangements continue, plot-based revisions that bring changes in land-use and increase in built-up conditions, negatively affect the quality of life. The plan revision decisions in which the negative impact on the quality of urban life are generally the increase of construction density in housing and commercial areas, reduction of social service areas, transformation of public spaces into private areas, transformation of residential areas into commercial and tourism areas. Therefore, it is revealed that the majority of the revision decisions involve the economic and political interventions appeared by liberal policies and the globalization process. Another interesting point raised out of the study is that social and environmental aspects of quality of life, although they are frequently mentioned in the literature, have not been reflected or considered as much within the framework of spatial intervention decisions.

As a result, the field study has shown that urban spatial interventions are predominantly to meet the rent-related demands on urban land but not focused on improving the quality of urban life. In this context, it is observed that urban interventions cannot be independent from economy and politics. Neoliberal policies and globalization process negatively affect the quality of urban life in urban environments. Such an intervention process reveals that the effectiveness of spatial plans should be questioned and the aims of the interventions should be discussed.

\section{Kaynakça/References}

Abbate, R., Grambalvo, O. ve Milito, A.M. (2001). Service and life quality: The case of Palermo. Social Indicators Reserach, 54, 275-308.

Andrews, C.J. (2001). Analyzing quality of place. Environment and Planning B: Planning and Design, 28, 201-217.

Avrupa Birliği ve Avrupa İstatistik Ofisi. (2004). Urban audit methodological handbook. Luxembourg. (2020, 1 Aralık) https://ec.europa.eu/eurostat/ramon/statmanuals/files/KS-BD-04-002-EN.pdf adresinden erişilmiştir.

BİB. (2008). Kentsel göstergeler kılavuzu. Ankara: Bayındırlık ve İskan Bakanlığı. Teknik Araştırma ve Uygulama Genel Müdürlügü Yayını.

Castells, M. (1997). Kent, sinff, iktidar. (Asuman Erendil, Çev.). Ankara: Bilim ve Sanat Yayınları. 
Cheung, C. (1997). Toward a theoretically based measurement model of the good life. Journal of Genetic Psychology, 158 (2), 200-215.

Cutter, Susan L. (1985). Rating places: A geographer's view on quality of life. Washington, D.C: Association of American Geographers/Library of Congress.

Demirkaya, Y. (2010). Çekmeköy'ün sosyo-ekonomik yapısı ve kentsel yaşam kalitesi, İstanbul: Çekmeköy Belediye Başkanlığı Yayını.

Diener, E. ve Suh, E. (1997). Measuring quality of life: Economic, social and subjective indicators. Social Indicators Research, 40, 189-216.

Dissart, J.C. ve Deller, S.C. (2000). Quality of life in the planning literature. Journal of Planning Literature, Vol.15, No.1.

Dülger Türkoğlu, H., Bölen, F., Baran, P.K. ve Marans, R.W. (2008). İstanbul'da yaşam kalitesinin ölçülmesi. İTÜ Dergisi/a Mimarlık, Planlama, Tasarım, 7 (2), 103-113.

Evcil Türksever, A.N. ve Atalık, G. (2001). Possibilities and limitations for the measurement of the quality of life in urban areas. Social Indicators Reserach, 53, 163-187

Garau, C. ve Pavan V.M. (2018). Evaluating urban quality: Indicators and assessment tools for smart sustainable cities. MDPI Journal Sustainability, 10, 575.

Ghulyan, H. (2017). Lefebvre'nin mekan kuramının yapısal ve kavramsal çerçevesine dair bir okuma. Çă̆daş Yerel Yönetimler Dergisi, 26, 1-29.

Harvey, D. (1985). The urban experience. Baltimore: The Johns Hopkins University Press.

Jeffres, L.W. ve Dobos, J. (1995). Separating people's satisfaction with life and public perceptions of the quality of life in the environment. Social Indicators Research, 34, 181-211.

Kamp, I.V., Leidelmeijer, K., Marsman, G. ve Hollander, A. (2003). Urban environmental quality and human well-being towards a conceptual framework and demarcation of concepts; a literature study. Landscape and Urban Planning, 65, 5-18.

Keskinok, H.Ç. (1998). Kentsel mekanın üretiminde raslantısallık sorunu üzerine. ODTÜ Mimarlık Fakültesi Dergisi, 18(1-2), 91-102.

Lefebvre, H. (2007). The production of space. (D. Nicholson Smith, Çev.). Oxford, UK: Balackwell Publishing. (1991).

Liu, B.C. (1976). Quality of life indicators in U.S. metropolitan areas: A statistical analysis. New York: Praeger Publishers.

Liu, B.C., Mulvey, T. ve Hsieh, C. (1986). Effects of educational expenditures on regional inequality in the social quality of life. American Journal of Economics and Sociology, 2, 131-144.

Marans, R.W. ve Stimson, R. (2011). Chapter 1 An overview of quality of urban life. R.W. Marans ve R.Stimson (Der.). Investigating quality of urban life: Theory, methods and empirical research, Social Indicators Reserach Series 45, Springer Science + Business Media B.V. 
Marsella, A.J., Levi, L. ve Ekblad, S. (1997) The importance of including qualityof-life indices in international social and economic development activities. Applied and Preventive Psychology, 6 (2), 55-67.

McCrea, R., Shyy, T.K. ve Stimson, R. (2006). What is the strength of the link between objective and subjective indidcators of urban quality of life?, Research in Quality of Life, 1, 79-96.

Mekansal Planlar Yapım Yönetmeliği. (2017, 17 Mayıs) Resmi Gazete (Sayı: 30069). https://www.resmigazete.gov.tr/eskiler/2017/05/20170517-2-1.pdf adresinden erişilmiştir.

Musschenga, A.W. (1997). The relation between concepts of quality of life. Journal of Medicine Philosophy 22 (1), 11-28.

Nakanishi, H. (2015). How does urban policy influence quality of life? the case of Canberra, Australia. Routledge TaylorEFrancis Group, Policy Studies, 36 (1), 72-91.

Organisation for Economic Co-operation and Development. (2017). How's life in Turkey?. OECD Publishing. (2020, 20 Kasim) http://www.oecdbetterlifeindex.org/ adresinden erişilmiştir.

Pacione, M. (1986). Quality of life in Glasgow: An applied geographical analysis. Environment and Planning A, 8, 1499-1520.

Pacione, M. (2003). Urban environmental quality and human wellbeing- A social geographical perspective. Landscape And Urban Planning, 65, 19-30.

Perloff, H. S. (1969). The quality of the urban environment: Essays on new resources in an urban age. Baltimore: Resource For The Future, The Johns Hopkins Press.

Raphael, D., Renwick, R., Brown, I. ve Rootman, I. (1996). Quality of life indicators and health: Current status and emerging conceptions. Social Indicators Research, 39 (1), 65-88.

Rogerson, R.J., Findlay, A.M. ve Morris, A.S. (1989). Indicators of quality of life: Some methodological issues. Environment and Planning A. 21, 1655-1666.

Salihoğlu, T. ve Türkoğlu, H. (2019). Konut çevresi ve kentsel yaşam kalitesi. Megaron, 14 (1), 203-217.

Santos, L.D. ve Martins, I. (2007). Monitoring urban quality of life: The porto experience. Social Indicators Research, 80, 411-425.

Shoja, S., Salehi, S.K. ve Ansari, R. (2015). Subjective assessment of urban quality of life indices, case study: Yazd, 2011-2012. Armanshahr Architecture $\mathcal{E}$ Urban Development, 8 (14), 165-175.

Smith, N. (2002). New globalism, new urbanism: Gentrifaction as global urban strategy. Antipode A Radical Journal of Geography, 34(3), 427-450.

Soja, E. (1980). Socio-spatial dialectic. Annals of the Association of American Geographers, 70 (2), 207-225.

Szalai, A. (1980). The meaning of comparative research on the quality of life. A. Szalai ve F. M. Andrews (Der.), In the quality of life: Comparative studies içinde (s. 7-24). London: Sage. 
Tekeli, İ. (2009). Gündelik yaşam, yaşam kalitesi ve yerellik yazıları. İlhan Tekeli Toplu Eserleri.12. İstanbul: Tarih Vakf1 Yurt Yayınları, 79-141.

Tekeli, İ., Güler, Ç., Vazioğlu, S., Algan, N. ve Dündar, A.K. (2003). Yaşam kalitesi göstergeleri: Türkiye için bir veri sistemi önerisi. Ankara: Türkiye Bilimler Akademisi Raporları, 6.

Tesfazghi, E.S., Martinez Martin, J. ve Verplanke, J.J. (2010). Variability of quality of life at small scales: Addis Ababa, Kirkos Sub-City. Social Indicator Research, Springer, 98, 73-88.

Ülengin, B., Ülengin, F. ve Güvenç, Ü. (2001). A Multidimensional approach to urban quality of life: The case of İstanbul. European Journal of Operational Research, 130, 361-374.

Veenhoven, R. (2000). The four qualities of life. Journal of Happiness Studies, 1, 1-39.

Wish, N.B. (1986). Are we really measuring quality of life. American Journal of Economics and Sociology, 3, 343-358.

Yakın İnan, Ö. ve Özdemir Sönmez, N. (2019). Kentsel yaşam kalitesi ölçüm yöntemlerinin geliştirilmesi. International Journal of Economics, Politics, Humanities \& Social Sciences, 2, 3.

Türkiye İstatistik Kurumu Adrese Dayalı Nüfus Kayıt Sistemi (ADNKS) (2020, 15 Kasım) https://www.tuik.gov.tr/ adresinden erişilmiştir.

Çankaya Belediyesi (2020, 15 Kasım) http://www.cankaya.bel.tr/pages/14/RAKAMLARLA-CANKAYA/ adresinden erişilmiştir. 